\title{
EFEKTIVITAS INSTAGRAM SEBAGAI MEDIA PROMOSI PRODUK OLAHAN PERTANIAN KOPI DI RUMAH KOPI SUNDA HEJO
}

\section{The Effectiveness Of Instagram as a Promotion Media of Product Processed Agriculture Coffee in Rumah Kopi Sunda Hejo}

\author{
Adzania Mutiara Firdaus*), Hadiyanto \\ Departemen Sains Komunikasi dan Pengembangan Masyarakat, Fakultas Ekologi Manusia, Institut Pertanian \\ Bogor, Darmaga Bogor 16680, Indonesia \\ ${ }^{*}$ E-mail: adzaniafirdaus@ @mail.com;
}

Diterima: 23-10-21 | Disetujui: 19-01-22 | Publikasi online: 20-01-22

\begin{abstract}
Agro-industry is an industrial activities by making use of agricultural results processed into processed agricultural product. UMKM are small and medium scale of agro-industry that sell local Indonesian products. In the development of UMKM, need to carry out promotional activities to introduce products to consumers widely, one of them using Instagram social media. The purpose of this study is to analyze the characteristic of Instagram social media, to analyze the exposure of @ sundahejo, to analyze of the effectiveness of Instagram as a promotion media, to analyze the relationship between consumer characteristics with the effectiveness of Instagram as a promotion media, to analyze the relationship between the characteristic of Instagram social media with the effectiveness of Instagram as a promotion media, and to analyze the relationship between the exposure of @sundahejo with the effectiveness of Instagram as a promotion media. This study use survey method by using quantitative data in the form of a questionnaire supported by qualitative data in the form of in-depth interviews. The number of respondents in this study were 50 respondent. The result showed that Instagram was effective in stimulating attention, interest and desire. Entering action stage Instagram is quite effective in encouraging respondents to take an action on Sunda Hejo coffee products.
\end{abstract}

Keywords: Local coffee, Instagram as a media promotion, AIDA Model

\section{ABSTRAK}

Agroindustri merupakan kegiatan industri dengan memanfaatkan hasil pertanian yang diolah menjadi produk olahan pertanian. UMKM merupakan agroindustri skala kecil dan menengah yang menjual produk lokal. Dalam pengembangan usaha UMKM, perlu dilakukan kegiatan promosi untuk memperkenalkan produk kepada konsumen secara luas, salah satunya menggunakan media sosial Instagram. Tujuan penelitian ini adalah menganalisis karakteristik pesan dalam media sosial Instagram, menganalisis keterdedahan terhadap akun@sundahejo, menganalisis efektivitas Instagram sebagai media promosi, menganalisis hubungan antara karakteristik konsumen dengan efektivitas Instagram sebagai media promosi, menganalisis hubungan antara karakteristik pesan dalam media sosial Instagram dengan efektivitas Instagram sebagai media promosi, dan menganalisis hubungan antara keterdedahan terhadap akun@sundahejo dengan efektivitas Instagram sebagai media promosi. Penelitian ini menggunakan metode survei dengan data kuantitatif berupa kuesioner yang didukung oleh data kualitatif berupa wawancara mendalam. Jumlah responden dalam penelitian ini adalah 50 responden. Hasil penelitian menunjukkan Instagram efektif dalam menstimulasi perhatian, ketertarikan dan keinginan responden. Memasuki tahap action efektivitas Instagram tergolong cukup efektif mendorong responden dalam melakukan tindakan terhadap produk kopi Sunda Hejo.

Kata Kunci: Kopi lokal, Media promosi Instagram, Model AIDA

Content from this work may be used under the terms of the Creative Commons Attribution-ShareAlike 4.0 International. Any further distribution of this work must maintain attribution to the author(s) and the title of the work, journal citation and DOI. 


\section{PENDAHULUAN}

Pertanian merupakan kegiatan manusia yang memanfaatkan sumberdaya hayati untuk memenuhi kebutuhan hidupnya. Kegiatan pemanfaatan sumberdaya hayati tersebut dilakukan dengan mengolah hasil pertanian menjadi bahan pangan, bahan baku industri dan bahan baku lainnya. Pengolahan hasil pertanian tersebut dapat dilakukan dengan kegiatan agroindustri atau industri pertanian. Agroindustri adalah pengolahan hasil pertanian dan karena itu agroindustri merupakan bagian dari enam subsistem agribisnis yang disepakati selama ini yaitu subsistem penyediaan sarana produksi dan peralatan, usaha tani, pengolahan hasil (agroindustri), pemasaran, sarana dan pembinaan (Soeharjo 1991). Agroindustri merupakan kegiatan industri dengan memanfaatkan hasil pertanian yang diolah menjadi produk-produk yang memiliki nilai tambah. Salah satu kegiatan agroindustri dalam mengolah hasil pertanian adalah pengolahan pangan. Agroindustri turut berkontribusi dalam perekonomian nasional. Peranan agroindustri terhadap perekonomian nasional adalah dapat meningkatkan nilai tambah, meningkatkan kualitas hasil, meningkatkan penyerapan tenaga kerja, meningkatkan keterampilan produsen, dan meningkatkan pendapatan (Soekartawi 2000). Kegiatan agroindustri pengolahan pangan semakin berkembang salah satunya didorong oleh kebutuhan manusia yang semakin banyak untuk pemenuhan kebutuhan pangannya.

Salah satu produk pangan yang sedang diminati oleh masyarakat adalah produk kopi. Seiring dengan kemajuan dan perkembangan zaman, telah terjadi peningkatan kesejahteraan dan perubahan gaya hidup masyarakat Indonesia yang akhirnya mendorong terhadap peningkatan konsumsi kopi. Hal ini terlihat dengan adanya peningkatan pemenuhan kebutuhan dalam negeri yang pada awal tahun 90an mencapai 120.000 ton, dewasa ini telah mencapai sekitar 180.000 ton (Direktorat Kajian Strategis dan Kebijakan Pertanian IPB 2017). Menurut penelitian Rahmah (2014) saat ini sekitar $92 \%$ produksi kopi berada di bawah petanipetani kecil atau koperasi. Besaran persentase inilah yang menjadikan banyak pelaku Usaha Mikro Kecil Menengah di Indonesia dewasa ini sangat tertarik untuk menjadikan kopi sebagai produk usahanya.

Usaha Mikro Kecil Menengah (UMKM) merupakan salah satu sektor dalam agroindustri yang memberikan dampak yang baik dalam perekonomian Indonesia. Menurut pasal 3 Undang - Undang No 20 Tahun 2008 tentang UMKM menyebutkan bahwa Usaha Mikro, Kecil, dan Menengah bertujuan menumbuhkan dan mengembangkan usahanya dalam rangka membangun perekonomian nasional berdasarkan demokrasi ekonomi yang berkeadilan. Peran penting UMKM dalam membangun perekonomian nasional adalah terciptanya lapangan kerja baru dan tercipta unit-unit kerja baru yang menggunakan tenaga baru yang dapat mendukung pendapatan rumah tangga, selain kedudukannya Hal ini ditunjukan dengan UMKM mampu menyerap tenaga kerja sebanyak 85 juta hingga 107 juta pekerja dari tahun 1998 sampai tahun 2012 (BPS 2013), meskipun demikian bisnis UMKM masih banyak mengalami kendala. Salah satu kendalanya yaitu sistem pemasaran produk yang belum modern. Berdasarkan permasalahan yang ada, perlu adanya perhatian lebih dalam pengembangan sistem pemasaran agar bisnis UMKM dapat bersaing dengan perusahaan yang berskala besar. Pengembangan sistem pemasaran dilakukan untuk mengenalkan produk kepada konsumen, salah satunya menyediakan informasi mengenai produk ke pasaran.

Terdapat banyak UMKM yang memproduksi olahan pertanian kopi yang dengan kualitas specialty coffee, salah satunya adalah Rumah Kopi Sunda Hejo. UMKM Rumah Kopi Sunda Hejo merupakan sebuah kegiatan agribisnis pengembangan dari usaha bersama koperasi "Klasik Beans" yang menjual produk olahan kopi asli di Indonesia. Keterbatasan petani dalam menjual hasil penanaman kopi menggerakan para pendiri koperasi "Klasik Beans" untuk membantu mengembangkan para petani dan menjual hasil tanam petani dalam bentuk produk kopi Sunda Hejo. UMKM Rumah Kopi Sunda Hejo mendapatkan bahan baku dari paguyuban petani kopi yang bernama "Paguyuban Tani Sunda Hejo". Rumah Kopi Sunda Hejo mempunyai tujuan untuk mengolah kopi bukan hanya menjadi produk mentah namun menjadi sebuah minuman yang siap dinikmati konsumennya. Rumah Kopi Sunda Hejo harus melakukan kegiatan promosi untuk memasarkan produk kopinya ke masyarakat luas.

Menurut Chrismardani (2014) salah satu langkah yang disarankan untuk dilakukan adalah perluasan pemasaran. Kegiatan pemasaran yang dilakukan dapat membawa keuntungan bagi UMKM itu 
sendiri dalam memperkenalkan produknya dan juga membawa keuntungan bagi konsumen yang mendapatkan informasi tentang produk yang ingin dikonsumsi. Menurut Kotler dan Armstrong (2008) menyatakan bahwa dalam pemasaran terdapat bauran pemasaran yang disebut dengan 4P yaitu product, price, promotion, dan place. Salah satu bauran pemasaran yang dapat dilakukan untuk membujuk konsumen dalam membeli produk olahan pertanian adalah melalui bauran promosi. Menurut Kotler dan Keller (2012) komunikasi pemasaran atau bauran promosi adalah sarana yang digunakan perusahaan dalam upaya untuk menginformasikan, membujuk, dan mengingatkan konsumen baik secara langsung maupun tidak langsung tentang produk dan merek yang mereka jual.

Penyebaran informasi sebuah produk pertanian perlu menggunakan teknologi agar dapat secara cepat diketahui oleh konsumen. Salah satu cara memasarkan suatu produk melalui promosi yaitu dengan iklan melalui media konvensional seperti koran, majalah, brosur, leaflet, dan media sosial seperti Instagram, facebook, website dan twitter. Seiring dengan berkembangnya zaman, UMKM lebih aktif memasarkan sebuah promosi melalui media sosial karena dianggap dapat menjangkau wilayah yang besar dan penyebaran informasi yang lebih cepat. Menurut Sulianta (2014) media sosial mampu menyebarkan informasi dengan cepat dan daya jangkau yang luar biasa dibandingkan dengan media manapun. Salah satu media sosial yang sedang ramai digunakan oleh masyarakat dengan berbagai lapisan usia adalah Instagram. Memasarkan suatu produk melalui media promosi Instagram dapat membantu perusahaan lebih mudah dan cepat untuk memasarkan produknya. UMKM Rumah Kopi Sunda Hejo menggunakan media sosial Instagram dalam memasarkan produknya ke khalayak luas.

Komunikasi pemasaran melalui media Instagram dikatakan efektif apabila tujuan dari komunikasi pemasaran tercapai, selain itu komunikasi pemasaran dikatakan efektif melihat sejauh mana perubahan sikap dan perilaku yang konsumen terhadap produk setelah mengetahui pesan yang disebarkan melalui media promosi. Efektivitas promosi melalui media sosial Instagram diukur dengan tahapan dalam Model AIDA. Model AIDA merupakan singkatan dari Attention, Interest, Desire, dan Action yang digunakan untuk melakukan analisa pola pikir konsumen terhadap produk setelah melihat pesan promosi melalui media. Menurut Kotler dan Keller (2009), mengukur efektivitas media promosi dapat menggunakan Model AIDA. Konsep AIDA digunakan untuk melihat pemahaman konsumen tentang apa yang ia inginkan terhadap produk yang dipromosikan UMKM Rumah Kopi Sunda Hejo melalui Instagram.

Tujuan penulisan terkait "Efektivitas Instagram sebagai Media Promosi Produk Olahan Pertanian Kopi di Rumah Kopi Sunda Hejo" ini yaitu: (1) Menganalisis karakteristik pesan dalam media sosial Instagram yang dibagikan Rumah Kopi Sunda Hejo; (2) Menganalisis keterdedahan konsumen terhadap akun@sundahejo dalam media sosial Instagram; (3) Menganalisis efektivitas Instagram sebagai media promosi pada produk olahan pertanian kopi di Rumah Kopi Sunda Hejo; (4) Menganalisis hubungan antara karakteristik konsumen dengan efektivitas Instagram sebagai media promosi pada produk olahan pertanian kopi di Rumah Kopi Sunda Hejo; (5) Menganalisis hubungan antara karakteristik pesan dalam media sosial Instagram dengan efektivitas Instagram sebagai media promosi pada produk olahan pertanian kopi di Rumah Kopi Sunda Hejo; dan (6) Menganalisis hubungan antara keterdedahan terhadap akun @ sundahejo dalam media sosial Instagram dengan efektivitas Instagram sebagai media promosi pada produk olahan pertanian kopi di Rumah Kopi Sunda Hejo.

\section{PENDEKATAN TEORITIS}

\section{Usaha Mikro Kecil Menengah (UMKM)}

Menurut pasal 3 Undang - Undang No 20 Tahun 2008 tentang UMKM menyebutkan bahwa Usaha Mikro, Kecil, dan Menengah bertujuan menumbuhkan dan mengembangkan usahanya dalam rangka membangun perekonomian nasional berdasarkan demokrasi ekonomi yang berkeadilan. Perkembangan dan pertumbuhan UMKM setiap tahunnya semakin bertambah. Menurut LPPI dan Bank Indonesia (2015), UMKM memiliki proporsi sebesar 99,99\% dari total keseluruhan pelaku usaha di Indonesia atau sebanyak 56,54 juta unit. Jumlah ini mengalami peningkatan yang signifikan yang terus menerus. 
Perlu adanya strategi promosi dalam rangka pemberdayaan UMKM untuk memperkenalkan dan menumbuhkan minat konsumen dalam membeli produk. Berdasarkan hal tersebut, Khairani, Soviyant, dan Aznuriyandi (2018) mengatakan untuk menumbuhkan minat konsumen mencoba dan membeli produk UMKM, diperlukan upaya berbagai strategi pemasaran yang efektif salah satunya dengan kegiatan promosi. Salah satu media promosi yang dapat dilakukan UMKM sektor makanan dan minuman adalah melalui media sosial.

\section{Bauran Promosi}

Menurut Kotler dan Armstrong (2008) dalam pemasaran terdapat istilah bauran pemasaran (marketing mix) yang terdiri dari 4P, yaitu product, price, promotion, dan place. Menurut Kotler dan Keller (2012) komunikasi pemasaran atau bauran promosi adalah sarana yang digunakan perusahaan dalam upaya untuk menginformasikan, membujuk, dan mengingatkan konsumen baik secara langsung maupun tidak langsung tentang produk dan merek yang mereka jual.

Salah satu bauran promosi yang dapat digunakan dalam memasarkan produknya adalah iklan. Dewasa ini, banyak perusahaan yang mengadopsi iklan sebagai alat promosi menggunakan media sosial. Hal ini didukung dengan hasil dari penelitian Riyantoro dan Harmoni (2013) mengungkapkan bahwa iklan (advertising) sebagai salah satu bauran promosi dapat dilakukan melalui jejaring sosial guna mempengaruhi konsumen secara langsung maupun tidak langsung.

\section{Iklan}

Menurut Kusumastuti (2009) terdapat tiga tujuan utama dari periklanan yaitu menginformasikan, membujuk, dan mengingatkan. Menurut Kusumastuti (2009) terdapat beberapa media utama yang dapat digunakan untuk menyebarkan iklan yaitu surat kabar, televisi, radio, majalah dan direct mail. Seiring dengan perkembangan zaman, saat ini sudah banyak media-media yang dijadikan alat untuk penyebaran iklan. Media-media tersebut yaitu media konvensional seperti koran, majalah, brosur, banner, media televisi, radio, dan media internet seperti website, dan media sosial. Perusahaan dapat menggunakan media-media dalam periklanan untuk mempromosikan produknya. Salah satu media promosi yang sering digunakan perusahaan pada saat ini adalah media sosial.

\section{Media Sosial Instagram}

Media sosial merupakan sebuah media daring dimana penggunanya dapat berkomunikasi, berdiskusi, dan membentuk jejaring sosial di dalamnya. Media sosial merupakan sebuah media online, dengan para penggunanya bisa dengan mudah berpartisipasi, berbagi, dan menciptakan isi meliputi blog, jejaring sosial, wiki, forum dan dunia virtual. Selain itu, media sosial juga dapat menjadi sarana promosi untuk memperkenalkan produk sebuah perusahaan ke pasaran. Salah satu aplikasi platform dalam media sosial yang sedang digunakan banyak orang saat ini adalah Instagram. Instagram merupakan aplikasi yang dapat digunakan oleh setiap orang dalam setiap kalangan, didalamnya terdapat berbagai macam fitur. Saat ini Instagram sedang diminati banyak perusahaan untuk mempromosikan produk yang dijualnya. Hal tersebut dilakukan karena pengguna Instagram berasal dari berbagai kalangan dan menyebar diseluruh dunia. Menurut Wurinanda (2015) terdapat beberapa karakteristik Instagram, yaitu media sosial dengan fasilitas upload foto dan video, menguntungkan konsumen karena dapat melihat secara langsung produk yang ditawarkan, memuat informasi secara lengkap melalui caption yang diberikan pelaku usaha, fasilitas hashtag (tanda pagar) untuk memudahkan konsumen mencari tahu produk yang diinginkan.

\section{Karakteristik Pesan dalam Media Sosial Instagram}

Sebuah informasi atau pesan yang disampaikan kepada khalayak harus dapat dimengerti oleh khalayak. Informasi harus lengkap, jelas, singkat, padat dan kalimatnya. Karakteristik pesan dalam media sosial Instagram dilihat dari perhatian konsumen terhadap pengemasan pesan dan aktivitas promosi yang dilakukan oleh admin melalui Instagram. Shimp (2003) mengemukakan bahwa untuk 
mengukur efektivitas internet dapat dilihat dari frekuensi kunjungan pelanggan terhadap akun media sosial produk, frekuensi pesan dan feedback, tingkat daya tarik pesan, lama kunjungan, serta jalan yang ditempuh untuk mencapai situs-situs media tertentu. Menurut Oktaviani (2018) dalam penelitiannya menjelaskan media Instagram dapat efektif dalam melakukan promosi jika karakteristik pesan dalam media sosial Instagram dalam media Instagram (kelengkapan informasi, frekuensi pesan, kejelasan informasi dan daya tarik foto) dapat mempengaruhi efektivitas promosi. Tingkat daya tarik pesan merupakan pesan yang dikemas semenarik mungkin dalam bentuk foto maupun video untuk mendapatkan respon positif dari konsumen, kejelasan informasi merupakan informasi yang disajikan oleh pemasar kepada konsumen mengenai produk secara jelas, lengkap dan sesuai dengan yang sebenarnya, frekuensi pesan merupakan seberapa sering responden melihat pesan promosi yang dibagikan admin di timeline mereka. Indikator karakteristik pesan dalam media sosial Instagram tersebut dapat menjadi salah satu faktor penentu efektivitas media promosi.

\section{Keterdedahan terhadap Akun dalam Media Sosial Instagram}

Keterdedahan menurut Shore dalam Permatasari (2016) adalah kegiatan mendengar, melihat, dan membaca, atau secara lebih umum memberikan sejumlah perhatian kepada suatu pesan yang disampaikan dengan menggunakan media sebagai perantara. Keterdedahan konsumen merupakan tingkat paparan responden terhadap media sosial Instagram sebagai media promosi. Paparan responden terhadap informasi produk didapatkan melalui usaha responden mencari pesan sebelum menentukan sikap. Menurut Rodman (2006), keterdedahan media merupakan sebuah proses pada seseorang untuk mencari pesan yang dapat membantu mereka dalam menentukan sikap. Menurut Ardianto dan Komala (2005) menyatakan keterdedahan khalayak terhadap media meliputi jenis media yang digunakan, frekuensi penggunaan (frequency), maupun durasi penggunaan (longevity).

\section{Efektivitas Media Promosi}

Menurut Mahmudi (2005) efektivitas adalah hubungan antara output (hasil) dengan tujuan, sejauh mana output yang dihasilkan sesuai dengan tujuan yang diharapkan. Efektivitas media promosi digunakan untuk melihat sejauh mana perubahan sikap dan perilaku yang konsumen terhadap produk setelah mengetahui pesan yang disebarkan melalui media promosi. Promosi dikatakan efektif apabila tujuan dari promosi tercapai dan konsumen sebagai sasaran dalam promosi mengerti makna dari pesan yang dibagikan oleh pemasar. Konsumen yang melihat pesan promosi dapat merespon dengan perubahan sikap dan perilaku hingga melakukan tindakan pembelian. Salah satu cara untuk mengukur efektivitas dari media promosi dapat menggunakan model AIDA (Attention, Interest, Desire, Action). Menurut Kotler dan Keller (2009) Model AIDA merupakan suatu pesan yang harus mendapatkan perhatian, menjadi ketertarikan, menjadi minat, dan mengambil tindakan. Tahap-tahap konsumen merespon iklan dengan model AIDA dikutip dari Google Book "Advertising and Promotion: an IMC Perspective” karya Shah dan D'Souza (2014), penjelasan aspek-aspek AIDA adalah sebagai berikut: (1) Perhatian (Attention) Perhatian adalah tahap pertama dari menilai suatu efektivitas promosi yang dilakukan oleh suatu perusahaan. Pesan yang dirancang harus memiliki keunikan tersendiri dan komunikatif sehingga memberikan gambaran kepada konsumen akan suatu produk; (2) Ketertarikan (Interest) Tahap ini, konsumen sudah sadar tentang produk kemudian tertarik dengan produk tersebut. 
Pemasar perlu mengetahui apa yang konsumen rasakan tentang produk mereka. Ketertarikan muncul saat konsumen telah memiliki perhatian dan mungkin akan melakukan pencarian informasi yang lebih lengkap mengenai produk yang ditawarkan; (3) Keinginan (Desire) Setelah konsumen tertarik akan promosi yang disebar melalui media promosi, fungsi iklan adalah untuk membuat mereka cenderung kearah positif untuk membeli, dengan menciptakan keinginan dan preferensi untuk produk yang diiklankan. Keinginan dapat dibangun dengan menunjukkan bagaimana produk memenuhi kebutuhan spesifik konsumen dan dengan kreatif melakukan promosi yang berkualitas, nilai dan fitur penting lainnya; (4) Tindakan (Action) Tindakan yang diinginkan adalah mendorong konsumen untuk membeli produk dan melakukan pembelian ulang, tetapi dalam kasus tertentu juga bisa untuk menyebabkan kunjungan ritel dan memberitahu mengenai produk kepada orang lain. Iklan yang membangun merek atau citra, tidak akan langsung mendapatkan tindakan untuk pembelian, tetapi akan menciptakan preferensi dan keinginan yang pada akhirnya akan menghasilkan pembelian.

\section{Perilaku Konsumen}

Menurut Sumarwan (2011) perilaku konsumen adalah semua kegiatan, tindakan, serta proses psikologis yang mendorong tindakan tersebut pada saat sebelum membeli, ketika membeli, menggunakan, menghabiskan produk dan jasa setelah melakukan hal-hal di atas atau kegiatan mengevaluasi. Perusahaan harus memahami keragaman dan kesamaan konsumennya agar mampu menerapkan strategi promosi dan dapat mempengaruhi konsumen untuk membeli produknya. Menurut Sumarwan (2011) konsumen dalam memilih suatu produk akhirnya melakukan keputusan pembelian biasanya dipengaruhi oleh berbagai hal salah satunya gaya hidup. Faktor demografis merupakan salah satu faktor pembentuk gaya hidup. Indikator penyusunan faktor tersebut dilihat dari karakteristik konsumen. Karakteristik konsumen berdasarkan faktor demografis menurut Morissan (2010) meliputi usia, jenis kelamin, jenis pekerjaan, tingkat pendidikan, dan tingkat pendapatan.

\section{PENDEKATAN LAPANG}

Penelitian ini menggunakan metode kuantitatif yang didukung dengan data kualitatif untuk melihat hubungan antar variabel. Metode kuantitatif yang digunakan yaitu dengan penelitian survei dengan mengambil sampel responden dari populasi dan menggunakan kuesioner sebagai alat pengumpulan data. Data kualitatif didapatkan melalui teknik wawancara mendalam kepada informan dan beberapa responden secara langsung. Metode kuantitatif dengan data kualitatif dikombinasikan dalam upaya memperkaya data pada penelitian ini. Kedua metode tersebut dilakukan untuk mendapatkan data primer, sedangkan data sekunder dalam penelitian ini didapatkan dari literatur dan data yang terkait dan relevan dengan topik penelitian ini. Penelitian ini bersifat eksplanatori karena menjelaskan hubungan antara variabel melalui pengujian hipotesis. Penelitian eksplanatori merupakan penelitian penjelasan yang menyoroti hubungan kausal antara variabel-variabel penelitian dan menguji hipotesis yang telah dirumuskan sebelumnya (Effendi S dan Tukiran 2012).

Penelitian ini dilakukan di Rumah Kopi Sunda Hejo di Kp. Rancasalak RT.02/03, Rancasalak, Kadungora, Kabupaten Garut, Jawa Barat 44153. Lokasi penelitian ini dipilih secara sengaja (purposive sampling) dengan mempertimbangkan beberapa hal berikut: (1) Rumah Kopi Sunda Hejo merupakan sebuah UMKM yang menjual produk olahan pertanian kopi dari koperasi "Klasik Beans". Kopi tersebut didapat dari paguyuban tani yang merupakan mitra dari koperasi sebagai pemasok bahan baku utama dalam mengolah produk olahan kopi yang dijual; (2) Rumah Kopi Sunda Hejo menjual kopi lokal asli Indonesia khas Garut; dan (3) Rumah Kopi Sunda Hejo menerapkan kegiatan promosi yaitu iklan melalui media sosial Instagram dalam memasarkan produk kopi lokal.

Unit analisis pada penelitian ini adalah individu. Metode pengambilan data yang digunakan dalam penelitian ini adalah non probability sampling dengan teknik accidental sampling karena sampel yang diambil dari populasi tidak melalui prosedur pemilihan sampel dengan peluang yang sama karena tidak mengetahui jumlah populasi sehingga tidak dapat menentukan kerangka sampling. 
Teknik ini digunakan karena responden tidak bisa dikonfirmasi kesediaannya untuk mengisi kuesioner. Banyaknya sampel yang ditetapkan merupakan perkiraan akan relatif memadai untuk mendapatkan data yang diperlukan yang diperkirakan dapat mencerminkan populasinya. Jumlah responden dalam penelitian adalah 50 orang. Adapun 50 orang responden yang diambil adalah followers akun Instagram @sundahejo dengan kriteria pemilik akun aktif Instagram, mem-follow akunInstagram @sundahejo dan pernah melihat kegiatan promosi dari akunInstagram @sundahejo yang kemudian dipilih secara sengaja atau siapa saja yang dianggap dapat mewakili populasi berdasarkan kriteria yang sudah ditetapkan.

Informan dalam penelitian ini adalah pengelola UMKM Rumah Kopi Sunda Hejo yang memberikan informasi mengenai sejarah Rumah Kopi Sunda Hejo, peran para pelaku usaha dalam pengolahan kopi. Koordinator Rumah Kopi Sunda Hejo yang memberikan informasi mengenai jenis-jenis kopi dan proses pengolahan kopi. Marketing Communication yang memberikan informasi mengenai kegiatan pemasaran, promosi menggunakan media sosial Instagram. Public Relation yang memberikan informasi mengenai kegiatan yang dilakukan Rumah Kopi Sunda Hejo. Beberapa konsumen yang mengunjungi Rumah Kopi Sunda Hejo untuk melengkapi data yang dibutuhkan.

Data yang diperoleh adalah data primer dan sekunder. Data primer diperoleh melalui penyebaran kuesioner yang ditujukan kepada responden, wawancara mendalam kepada pengelola dan karyawan UMKM Rumah Kopi Sunda Hejo dan beberapa responden yang ditemui secara langsung di Rumah Kopi Sunda Hejo untuk diwawancarai. Wawancara mendalam dilakukan untuk memperoleh informasi yang lebih dalam mengenai UMKM Rumah Kopi Sunda Hejo. Kuesioner dilakukan untuk mendapatkan data dan informasi yang dibutuhkan dalam penelitian ini. Kuesioner tersebut sebelumnya akan diujikan dahulu kepada responden di luar responden yang akan diteliti untuk mengetahui tingkat validitas dan reliabilitasnya. Uji validitas dilakukan untuk melihat apakah kuesioner sebagai alat ukur dapat sesuai dengan apa yang ingin diukur, sedangkan uji reliabilitas digunakan untuk melihat sejauh mana alat ukur dapat dipercaya dan dapat digunakan kembali apabila digunakan dua kali. Uji validitas dan uji reliabilitas dilakukan sebelumnya di lokasi yang sama dengan tempat penelitian dengan jumlah responden sebanyak 10 responden, dan merupakan responden yang berbeda dengan responden asli. Data sekunder didapatkan dengan mengumpulkan data dari literatur terkait seperti buku, skripsi, jurnal, dan internet yang relevan dengan tujuan dari penelitian.

Penelitian ini mempunyai dua jenis data yang akan diolah dan dianalisis yaitu data kuantitatif dan data kualitatif. Data kuantitatif yang diperoleh dari kuesioner yang terkumpul kemudian diolah melalui Microsoft Excel 2010 dan Statistical Program for Social Sciences (SPSS version 22.0). Data kuantitatif yang didapat diuji menggunakan statistik Rank Spearman untuk data minimal ordinal dan diuji statistik Chi Square untuk data minimal nominal.

Data hasil wawancara mendalam sebagai data kualitatif menjadi informasi tambahan dan data pendukung untuk melengkapi hasil pengolahan data kuantitatif tersebut. Data kualitatif dianalisis melalui tiga tahap yaitu reduksi data, penyajian data, dan verifikasi.

\section{GAMBARAN UMUM LOKASI PENELITIAN}

\section{Sejarah Rumah Kopi Sunda Hejo}

Rumah Kopi Sunda Hejo merupakan salah satu coffee shop yang berlokasi di Kabupaten Garut dan sudah berdiri sejak 23 Juni 2017. Usaha coffee shop yang terbilang baru ini merupakan pengembangan dari usaha bersama dari koperasi "Klasik Beans" yang sudah berdiri sejak tahun 2011 yang didirikan oleh Pak Eko Purnomowidi, Pak Deny Glen, dan Pak Hamzah. Kopi Sunda Hejo terbentuk atas kepedulian relawan lingkungan yang melakukan kegiatan penghijauan akibat penggundulan hutan yang dilakukan oleh masyarakat sekitar hutan di Gunung Puntang yang gundul dari tahun 2003-2010. Atas dasar kepedulian tersebut, para relawan berinisiatif untuk melakukan berbagai penanaman tumbuhan yang bisa dimanfaatkan untuk pelestarian lingkungan bersama-sama dengan masyarakat sekitar yang sebelumnya melakukan penebangan liar. Seiring berjalannya waktu, masyarakat mengharapkan hasil dari kegiatan pelestarian tidak hanya untuk lingkungan saja tetapi juga untuk meningkatkan perekonomian mereka. Melihat komoditas kopi merupakan salah satu dari tanaman konservasi yang lebih stabil daripada komoditas lainnya dalam penghijauan lingkungan dan kestabilan harga kopi dalam sistem ekonomi pasar, sehingga pada tahun 2010 
dibentuk Paguyuban Tani Sunda Hejo yang kemudian dibentuk Koperasi "Klasik Beans" bersamasama para petani untuk menanam komoditas kopi dan mulai menjualnya ke pasar. Seiring berjalannya waktu para pendiri Koperasi "Klasik Beans" membuat kedai Rumah Kopi Sunda Hejo sebagai tempat untuk masyarakat bisa menikmati kopi Sunda Hejo secara langsung.

Rumah Kopi Sunda Hejo menjual beragam jenis kopi baik seduhan maupun kopi kemasan. Harga dari produk kopi kemasan berbeda-beda sesuai dengan takaran dan kualitas kopinya, berkisar Rp 30.000-Rp 150.000, sedangkan harga dari kopi seduhan relatif murah berkisar Rp 15.000-Rp 20.000. Saat ini pengunjung dari Rumah Kopi Sunda Hejo berasal dari berbagai wilayah seperti Bandung, Jakarta, Bogor, Garut, dan Tasik. Mayoritas pengunjung Rumah Kopi Sunda Hejo adalah masyarakat yang berdomisili di Garut. Pengunjung biasanya datang di waktu-waktu prime time seperti sore dan malam hari.

\section{Hubungan Kerjasama dengan Petani dan pelaku Produksi Lainnya}

Rumah Kopi Sunda Hejo merupakan coffee shop yang menjadi wadah konsumen untuk merasakan langsung seduhan kopi lokal asli Garut. Biji kopi yang dijual merupakan biji Kopi Sunda Hejo. Suatu rangkai pengolahan kopi dari penanaman hingga seduh, terdapat beberapa pelaku produksi yang memiliki peran masing-masing dan saling berkesinambungan dalam menciptakan kopi yang berkualitas. Pengolahan kopi dari proses tanam, proses produksi hingga siap minum melibatkan petani, roaster, dan barista.

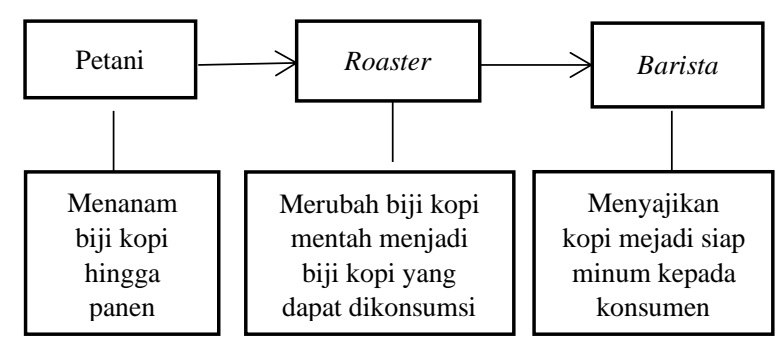

\section{Gambar 1 Para Pelaku Produksi dan Perannya Dalam Proses Pengolahan Kopi}

Sebuah kegiatan promosi secara langsung dapat memberikan dampak positif kepada para pelaku produksi yang berhubungan dengan proses pengolahan kopi. Keberlangsungan bisnis dari Rumah Kopi Sunda Hejo secara langsung terasa manfaatnya bagi seluruh pelaku produksi.

\section{Media Sosial Instagram sebagai Media Promosi}

Rumah Kopi Sunda Hejo melakukan kegiatan pemasaran dalam memasarkan produknya kepada masyarakat. Kegiatan promosi yang dilakukan Rumah Kopi Sunda Hejo bertujuan untuk memberikan informasi mengenai produk Kopi Sunda Hejo kepada konsumen hingga mendorong konsumen untuk mengunjungi Rumah Kopi Sunda Hejo dan melakukan pembelian produk Kopi Sunda Hejo. Kegiatan promosi yang dilakukan Rumah Kopi Sunda Hejo adalah iklan di berbagai media internet dan media sosial. Iklan tersebut disebarkan melalui Website (https://rumahkopisundahejo.business.site), media sosial Facebook (Rumah Kopi Sunda Hejo) dan Instagram (@sundahejo). Melalui Website Rumah Kopi Sunda Hejo menyebarkan informasi mengenai lokasi, foto produk dan tempat, serta beragam artikel mengenai kopi Sunda Hejo. Media sosial Facebook digunakan oleh Rumah Kopi Sunda Hejo untuk menyebarkan informasi mengenai produk kepada para konsumen yang sudah menjadi langganan, berisi tentang informasi stok kopi dan beberapa menu seduhan kopi.

Media sosial Instagram merupakan fokus utama media promosi Rumah Kopi Sunda Hejo dalam melakukan kegiatan promosi. Hal tersebut disebabkan karena media sosial Instagram dapat menjangkau khalayak secara luas dari berbagai kalangan usia dan proses penyebaran informasinya cepat. Sesuai dengan sasaran konsumen dari Rumah Kopi Sunda Hejo yaitu seluruh kalangan usia baik muda sampai tua, dan berbagai kalangan dengan tingkat pendapatan rendah sampai tinggi. Selain itu, Instagram menyediakan fitur business yang gratis yang tidak tersedia di media sosial 
lainnya, sehingga penggunanya dapat menyebarkan konten berupa foto dan video sebanyakbanyaknya kepada khalayak.

Akun Instagram @ sundahejo memiliki followers sebanyak 4.300 terhitung pada bulan April 2019. Isi dari postingan Instagram Rumah Kopi Sunda Hejo adalah informasi mengenai produk kopi yaitu jenis-jenis kopi yang dijual, proses pengolahan kopi, kegiatan/event yang pernah dan sedang dilakukan oleh Rumah Kopi Sunda Hejo, dan edukasi mengenai kopi. Informasi tersebut dikemas dalam bentuk foto dan video yang kemudian di share melalui post dengan penjelasan berupa Caption. Caption tersebut menjabarkan berbagai informasi mengenai promosi atau hanya sekedar menyapa followers, dan lainnya. Selain melalui post foto atau video yang di share oleh Rumah Kopi Sunda Hejo juga di share melalui Insta Story. Rumah Kopi Sunda Hejo juga menambahkan hashtag dalam post foto dan video untuk memudahkan pencarian oleh pengguna Instagram mengenai produk kopi di Rumah Kopi Sunda Hejo.

Konsep promosi yang dilakukan oleh Rumah Kopi Sunda Hejo melalui Instagram memiliki konsep yang unik dan berbeda dengan konsep promosi produk-produk lainnya. Kegiatan promosi Rumah Kopi Sunda Hejo lebih menunjukan filosofi dari kopi itu sendiri, bagaimana proses pengolahan kopi yang baik sehingga menciptakan biji kopi yang berkualitas, berbagai macam proses brewing dengan menggunakan alat seduh manual maupun modern dengan berbagai cita rasa yang berbeda, menggambarkan Rumah Kopi Sunda Hejo sebagai tempat yang nyaman untuk berkunjung, kegiatan sosial yang dilakukan Rumah Kopi Sunda Hejo bersama petani dan masyarakat, event yang dilakukan oleh Rumah Kopi Sunda Hejo di berbagai daerah di Indonesia, dan Caption yang berisi kata-kata motivasi dan cerita tentang kopi.

\section{HASIL DAN PEMBAHASAN}

\section{Karakeristik Responden Penelitian}

Karakteristik responden merupakan salah satu variabel di dalam penelitian ini. Jumlah responden yang diambil dalam penelitian ini sebanyak 50 responden dilihat dari indikator usia, jenis kelamin, jenis pekerjaan, tingkat pendidikan, dan tingkat pendapatan. Usia diukur menggunakan standar deviasi dengan tiga kategori yaitu muda (14-19 tahun), sedang (20-25 tahun) dan dewasa (26-42 tahun). Usia yang dominan dalam penelitian ini adalah kategori muda yaitu sebanyak 21 orang dengan persentase 42 persen. Indikator jenis kelamin dibagi menjadi jenis kelami laki-laki dan perempuan. Responden didominasi oleh jenis kelamin laki-laki yaitu sebanyak 30 orang dengan persentase 60 persen. Jenis pekerjaan dikategorikan menjadi TNI/POLRI, pekerja swasta, wiraswasta, pelajar/mahasiswa, ibu rumah tangga, profesi lainnya, dan belum bekerja. Jenis pekerjaan didominasi oleh pelajar/mahasiswa yaitu sebanyak 30 orang atau 60 persen. Indikator tingkat pendidikan dibagi menjadi rendah (tamat SD, tamat SMP), sedang (tamat SMA), tinggi (tamat Perguruan Tinggi). Tingkat pendidikan responden didominasi oleh golongan sedang (tamat SMA) sebanyak 29 orang dengan persentase 58 persen. Indikator tingkat pendapatan menggunakan standar deviasi dan diperoleh tiga kategori yaitu rendah (Rp 300.000-Rp 1.100.000), sedang (Rp 1.200.000-Rp 3.300.000) dan tinggi ( Rp 3.400.000-Rp 10.000.000). Tingkat pendapatan didominasi oleh golongan rendah sebanyak 22 responden dengan persentase 44 persen.

\section{Karakteristik Pesan dalam Media Sosial Instagram}

Karakteristik pesan dalam media sosial Instagram akun @ sundahejo dilihat dari tiga indikator, yaitu tingkat daya tarik pesan, kejelasan informasi dan frekuensi pesan. Indikator yang paling besar jumlah penilaian responden pada tingkat daya tarik pesan adalah Caption dan feeds (tata letak) pada laman akun@sundahejo menarik yaitu masing-masing sebanyak 28 responden dengan persentase 56 persen menjawab setuju. Indikator yang paling besar jumlah penilaian responden dalam kejelasan informasi adalah kejelasan informasi lokasi toko Rumah Kopi Sunda Hejo menjawab sangat setuju sebanyak 30 responden dengan persentase 60 persen. Indikator yang paling besar jumlah penilaian responden pada frekuensi pesan adalah kemunculan foto atau video melalui Insta Story dari akun Instagram @ sundahejo di timeline dalam seminggu sebanyak 32 responden dengan persentase 48 persen menjawab sering. Karakteristik pesan dalam media sosial Instagram yang dibagikan melalui akun @ sundahejo dalam media sosial Instagram tergolong sedang pada semua indikator yaitu pada indikator tingkat daya tarik pesan, kejelasan informasi dan frekuensi pesan. 


\section{Keterdedahan terhadap Akun @sundahejo dalam Media Sosial Instagram}

Penelitian ini melihat variabel keterdedahan terhadap media akun @sundahejo dalam media sosial Instagram yang dilihat pada indikator frekuensi mengakses akun @ sundahejo dalam media sosial Instagram dan durasi mengakses akun @ sundahejo dalam media sosial Instagram. Indikator frekuensi mengakses akun didapat dengan menggunakan standar deviasi dan hasilnya frekuensi responden dalam mengakses akun @ sundahejo dalam media sosial Instagram berada pada kategori jarang yaitu sebanyak 28 responden dengan persentase 56 persen membuka akun @ sundahejo sebanyak satu sampai dua kali dalam seminggu. Indikator durasi mengakses akun didapat dengan menggunakan standar deviasi dan hasilnya responden termasuk dalam kategori sedang yaitu sebanyak 24 responden dengan persentase 48 persen membutuhkan waktu selama empat sampai empat belas menit dalam satu kali akses akun Instagram @sundahejo.

\section{Efektivitas Instagram sebagai Media Promosi}

Penelitian ini melihat tingkat efektivitas media sosial Instagram sebagai media promosi menggunakan Model AIDA dengan empat tahapan yaitu tahap attention, interest, desire, dan action. Terjadi pengurangan jumlah responden dari setiap tahap dalam Model AIDA. Tahap pertama yaitu attention, sebanyak 50 responden berada pada tahap ini. Indikator pada tahap attention yang memiliki penilaian paling tinggi dari responden adalah indikator mengetahui lokasi toko Rumah Kopi Sunda Hejo melalui akun Instagram @sundahejo yaitu sebanyak 25 responden dengan persentase 50 persen menjawab setuju. Tahap interest, sebanyak 48 responden berada pada tahap ini. Indikator pada tahap interest yang memiliki penilaian paling tinggi dari responden adalah indikator tertarik untuk mengunjungi toko Rumah Kopi Sunda Hejo yaitu sebanyak 34 responden dengan persentase 70.8 persen responden menjawab sangat setuju.

Tahap selanjutnya yaitu desire, sebanyak 43 responden berada pada tahap ini. Indikator pada tahap desire yang memiliki penilaian paling tinggi dari responden adalah indikator ingin mengunjungi toko Rumah Kopi Sunda Hejo yaitu sebanyak 29 responden dengan persentase 67.4 persen. Responden sudah memiliki keinginan untuk mengetahui lebih lanjut informasi mengenai produk Kopi Sunda Hejo dengan bertanya kepada admin @sundahejo dan memiliki keinginan untuk membeli produk. Memasuki tahap action, sebanyak 35 responden berada pada tahap ini. Indikator pada tahap action yang paling banyak diberi pernyataan ya oleh responden adalah indikator memberitahu informasi mengenai produk kopi Sunda Hejo kepada teman atau kerabat yaitu sebanyak responden 25 responden dengan persentase 71.4 persen dan memberikan testimoni melalui media sosial yaitu sebanyak 22 responden dengan persentase 62.9 persen.

\section{Hubungan Karakteristik Konsumen dengan Efektivitas Instagram sebagai Media Promosi}

Berdasarkan hasil korelasi Rank Spearman pada hubungan usia tidak memiliki hubungan yang nyata terhadap efektivitas Instagram sebagai media promosi pada tahap attention, interest, desire, dan action. Hal tersebut disebabkan karena Rumah Kopi Sunda Hejo tidak mengemas pesan berdasarkan segmentasi usia. Indikator jenis kelamin dengan efektivitas Instagram sebagai media promosi pada tahap attention, interest, desire, dan action hanya berhubungan signifikan dengan tahap desire. Hal tersebut ditunjukan oleh keinginan responden laki-laki memiliki keinginan yang lebih tinggi dibanding responden perempuan untuk mengetahui lebih lanjut terhadap produk yang dipromosikan oleh Rumah Kopi Sunda Hejo melalui Instagram. Mayoritas responden laki-laki merupakan pecinta dan penikmat kopi, sehingga mereka lebih antusias terhadap informasi mengenai kopi.

Indikator jenis pekerjaan dengan efektivitas Instagram sebagai media promosi pada tahap attention, interest, desire, dan action hanya berhubungan signifikan dengan tahap interest. Hal tersebut disebabkan karena ketertarikan responden terhadap produk kopi muncul karena gaya hidup dan lingkungan pekerjaan responden. Indikator tingkat pendidikan dengan efektivitas Instagram sebagai media promosi pada tahapan AIDA tidak berhubungan nyata. Hal tersebut terjadi karena latar belakang responden bukan merupakan faktor dalam menentukan sikap responden terhadap pesan promosi yang dibagikan oleh akun @sundahejo. Indikator tingkat pendapatan dengan efektivitas Instagram sebagai media promosi pada tahapan AIDA tidak berhubungan nyata. Hal tersebut mengindikasikan bahwa tingkat pendapatan responden bukan merupakan faktor yang menentukan 
efektivitas sebuah promosi. Rumah Kopi Sunda Hejo menjual produk kopi dengan harga yang dapat dijangkau oleh berbagai tingkat pendapatan.

\section{Hubungan Karakteristik Pesan dalam Media Sosial Instagram dengan Efektivitas Instagram sebagai Media Promosi}

Berdasarkan hasil korelasi Rank Spearman pada hubungan antara tingkat daya tarik pesan berhubungan signifikan terhadap efektivitas Instagram sebagai media promosi pada tahap attention, interest, dan desire. Hal tersebut membuktikan pesan yang dikemas secara menarik akan membuat responden semakin perhatian terhadap produk, tertarik, hingga mendorong untuk berkeinginan lebih lanjut terhadap produk kopi Sunda Hejo Kejelasan informasi berhubungan signifikan dengan efektivitas Instagram sebagai media promosi tahap attention, interest, dan desire. Informasi yang dibagikan oleh akun @sundahejo secara jelas dan rinci menjadi faktor dalam peningkatan tingkat perhatian responden, ketertarikan, dan keinginan responden terhadap produk kopi yang dijual di Rumah Kopi Sunda Hejo. Frekuensi pesan berhubungan signifikan dengan efektivitas Instagram sebagai media promosi pada tahap interest, dan action. Hal tersebut menunjukan bahwa pesan yang dibagikan oleh admin @sundahejo secara terus menerus melalui Instagram dapat menarik responden hingga mendorong responden untuk melakukan tindakan terhadap produk kopi yang dijual di Rumah Kopi Sunda Hejo.

Hubungan Keterdedahan terhadap Akun@sundahejo dalam Media Sosial Instagram dengan Efektivitas Instagram sebagai Media Promosi

Kategori frekuensi mengakses akun @ sundahejo tidak memiliki hubungan nyata dengan efektivitas Instagram sebagai media promosi pada setiap tahap AIDA. Dominasi responden memiliki frekuensi kategori jarang dalam mengakses akun @ sundahejo. Responden tidak harus sering membuka akun @ sundahejo untuk mengetahui informasi mengenai produk, menimbulkan ketertarikan, membangkitkan keinginan, dan mendorong melakukan tindakan terhadap produk. Kategori durasi mengakses akun @ sundahejo hanya berhubungan nyata dengan efektivitas Instagram sebagai media promosi pada tahap action. Ini menunjukan responden membutuhkan waktu untuk mengakses akun @ sundahejo terlebih dahulu untuk menemukan informasi sesuai dengan yang dibutuhkan sebelum melakukan tindakan.

\section{KESIMPULAN}

(1) Karakteristik pesan dalam media sosial Instagram akun @ sundahejo dilihat pada kategori tingkat daya tarik pesan, kejelasan informasi dan frekuensi pesan. Ketiga kategori tersebut berada pada kategori sedang sehingga pesan yang disampaikan oleh admin @sundahejo melalui Instagram dinilai responden sudah cukup menarik, informasinya cukup jelas dan cukup sering muncul di timeline responden; (2) Keterdedahan terhadap akun @sundahejo dalam media sosial Instagram dilihat dari kategori frekuensi mengakses akun dan durasi mengakses akun. Kategori frekuensi mengakses akun, responden berada pada kategori rendah yaitu satu sampai dua kali akses dalam seminggu. Kategori durasi mengakses akun, responden berada pada kategori sedang yaitu membutuhkan waktu selama empat sampai lima belas menit dalam satu kali akses; (3) Media sosial Instagram sebagai media promosi efektif dalam menimbulkan attention (perhatian), interest (ketertarikan), dan desire (keinginan) pada mayoritas responden. Memasuki tahap action (tindakan) efektivitas Instagram sebagai media promosi tergolong cukup efektif. Terdapat penurunan efektivitas Instagram dan jumlah responden dari setiap tahapan AIDA. Instagram menjadi media promosi yang tepat dalam menimbulkan perhatian, menarik perhatian, dan membangkitkan keinginan terhadap produk kopi yang ditawarkan Rumah Kopi Sunda Hejo.

Kegiatan promosi melalui Instagram belum mampu mendorong responden dalam melakukan tindakan kunjungan dan pembelian, namun mampu mendorong responden untuk memberikan informasi tentang produk kepada orang lain dan melakukan testimoni tentang produk; (4) Terdapat hubungan nyata antara karakteristik responden indikator jenis kelamin dengan efektivitas Instagram sebagai media promosi tahap desire. Terdapat hubungan nyata antara indikator jenis pekerjaan dengan efektivitas Instagram sebagai media promosi tahap interest. Ketertarikan responden terhadap kopi muncul karena gaya hidup dan lingkungan pekerjaan; (5) Terdapat hubungan nyata antara variabel karakteristik pesan dalam media sosial Instagram indikator tingkat daya tarik pesan 
dengan efektivitas Instagram sebagai media promosi tahap attention, interest, dan desire. Kejelasan informasi berhubungan nyata dengan efektivitas Instagram sebagai media promosi pada tahap attention, interest, dan desire. Tingkat daya tarik pesan dan kejelasan informasi pada pesan promosi belum dapat mendorong responden dalam melakukan tindakan terhadap produk. Indikator frekuensi pesan hanya berhubungan nyata dengan efektivitas Instagram sebagai media promosi pada tahap interest dan action; dan (6) Tidak terdapat hubungan nyata antara keterdedahan terhadap akun @ sundahejo indikator frekuensi mengakses akun @ sundahejo dengan efektivitas Instagram sebagai media promosi pada seluruh tahapan AIDA. Durasi mengakses akun @sundahejo hanya berhubungan nyata dengan efektivitas Instagram sebagai media promosi tahap action. Hal ini dikarenakan responden membutuhkan waktu untuk mengakses akun @sundahejo terlebih dahulu untuk menemukan informasi sesuai dengan yang dibutuhkan sebelum melakukan tindakan terhadap produk.

\section{Saran}

(1) Promosi Rumah Kopi Sunda Hejo melalui Instagram perlu memperhatikan pengemasan pesan promosi kepada seluruh konsumen yang merupakan pengguna Instagram. Hal tersebut dibutuhkan agar pesan promosi dapat dimengerti oleh seluruh konsumen baik laki-laki maupun perempuan dan seluruh kalangan bukan hanya usia muda saja. Promosi melalui akun Instagram @sundahejo diarahkan bukan hanya untuk menimbulkan perhatian responden terhadap informasi mengenai produk saja namun dapat mendorong responden untuk melakukan tindakan seperti pembelian dan kunjungan. Hal tersebut dapat distimulus dengan kegiatan promosi yang lebih menarik seperti pengadaan discount dan mendapat free minuman setiap pembelian produk kopi dengan jumlah tertentu; (2) Promosi Rumah Kopi Sunda Hejo melalui Instagram perlu meningkatkan aktivitas promosi dan pesan promosi yang dibagikan. Tingkat daya tarik dari pesan promosi yang sudah diterapkan seperti kualitas foto atau video, Caption yang menarik, pemilihan kata dan bahasa, serta pesan persuasif yang dibagikan perlu ditingkatkan agar konsumen terdorong untuk melakukan tindakan pembelian produk. Perlu adanya perhatian terhadap kejelasan informasi dalam pesan promosi. Akun@sundahejo harus memberikan informasi yang dibutuhkan calon konsumen untuk meyakinkan konsumen dalam melakukan pembelian. Admin@sundahejo perlu memperhatikan waktu upload konten, sehingga pesan promosi bukan hanya post foto dan Insta Story yang sering dilihat oleh konsumen, namun post video juga dapat lebih diketahui oleh konsumen; dan (3) Penelitian selanjutnya disarankan untuk mengkaji lebih lanjut mengenai promosi melalui Instagram dengan memperhatikan sasaran konsumen yang akan dijadikan responden, sehingga dapat terlihat sejauh mana Instagram dapat memberikan informasi mengenai produk dan mendorong konsumen melakukan tindakan pembelian. Perlu adanya pengkajian lebih lanjut mengenai penggunaan berbagai bauran promosi lainnya bukan hanya media Instagram saja agar dapat menggambarkan sejauh mana efektivitas promosi suatu produk.

\section{DAFTAR PUSTAKA}

Ardianto E, Komala EL. 2005. Komunikasi Massa: Suatu Pengantar. Bandung (ID): Remaja Rosdakarya.

[BPS]. Badan Pusat Statistik. 2013. Statistik UMKM tahun 2012-2013. [internet]. [diunduh tanggal 16 Januari 2019]. Dapat diunduh di: www.bps.go.id

Chrismardani Y. 2014. Jurnal NeO-Bis. Komunikasi pemasaran terpadu: implementasi untuk UMKM. [Internet]. [diunduh pada 9 Februari 2018]. Vol. 8(2). Madura (ID): Universitas Trunojoyo Madura. Dapat diunduh pada: http://journal.trunojoyo.ac.id/neobis/article/view/472

Direktorat Kajian Strategis dan Kebijakan Pertanian IPB. 2017. Peran Komoditas Bagi Perekonomian Indonesia. [internet]. [diunduh tanggal 20 Juni 2019]. Dapat diunduh di: http://sustainability.ipb.ac.id/wp-content/uploads/ 2019/01/13.PERAN-KOMODITAS-KOPI-BAGI-PEREKONOMIAN-INDONESIA.pdf 
Effendi S, Tukiran. 2012. Metode Penelitian Survei. Jakarta (ID): LP3ES

Khairani Z, Soviyant E, Aznuriyanti. 2018. Efektivitas Instagram sebagai media promosi Pada UMKM Sektor Makanan dan Minuman Di Kota Pekanbaru. Jurnal Benefita. 3 (2). [internet]. [diunduh 22 November 2018]. Dapat diunduh di : 10.22216/jbe.v3i1.2738

Kotler P, Armstrong G. 2008. Prinsip-Prinsip Pemasaran. Edisi ke-12. Jakarta (ID): Erlangga.

Kotler P, Keller KL. 2009. Manajemen Pemasaran. (Edisi 13). Jakarta (ID): Erlangga.

Kotler P, Keller KL. 2012. Manajemen Pemasaran. (Edisi 12). Jakarta (ID): Erlangga.

Kusumastuti Y. 2009. Komunikasi Bisnis. Bogor (ID): IPB Press

[LPPI dan BI]. Lembaga Pengembangan Perbankan Indonesia dan Bank Indonesia. 2015. Profil Bisnis Usaha Mikro, Kecil dan Menengah (UMKM). [Internet]. [Diunduh pada tanggal 15 Januari 2019]. Jakarta (ID). Dapat diunduh di: http://www.bi.go.id/id/umkm/penelitian/nasional/kajian/Documents/Profil\%20Bisnis\%20U MKM.pdf

Mahmudi. 2005. Manajemen Kinerja Sektor Publik. Yogyakarta (ID): UPP AMP YKPN.

Morissan. 2010. Periklanan: Komunikasi Pemasaran Terpadu. Jakarta (ID): Kencana Prenada Media Group.

Oktaviani. 2018. Efektivitas Penggunaan Media Sosial Sebagai Media Promosi Wisata Umbul Ponggok Kabupaten Klaten. [skripsi]. Bogor (ID): Institut Pertanian Bogor.

Permatasari G. 2016. Efektivitas Media Sosial Instagram Sebagai Media Promosi Produk Olahan Pertanian "Yogurt Cimory”. [skripsi]. Bogor (ID): Institut Pertanian Bogor.

Rahmah K. 2014. Analisis strategi pemasaran kopi lokal di rumah kopi ranin. [Skripsi]. Bogor (ID): Institut Pertanian Bogor.

Riyantoro B, Harmoni A. 2013. Efektivitas Iklan Melalui Media Jejaring Sosial Sebagai Salah Satu Strategi Pemasaran Keripik Pedas Maicih. Jurnal Proceeding PESAT. 5 (5 Oktober). [internet]. [diunduh 15 November 2018]. Dapat diunduh di: http://www.ejournal.gunadarma.ac.id/index.php/pesat/article/viewFile/923/813

Rodman G. 2006. Mass Media In Changing World. First Edition. USA(US): Mc Graw and Hill Inc.

Shah K dan D‘Souza A. 2014. Advertising and Integrated Marketing Communications. New Delhi (IN): McGraw: Hill Education. [internet]. [diunduh pada 2 Februari 2019]. Dapat diunduh di:https://books.google .co.id/books?id=078zCgAAQBAJ\&printsec=frontcover\&hl=id\#v=onepage \&q\&f=false.

Shimp TA. 2003. Periklanan Promosi dan Aspek Tambahan Komunikasi Pemasaran terpadu. Jakarta (ID): Erlangga.

Soeharjo A. 1991. Konsep dan Ruang Lingkup Agroindustri. Jakarta (ID): Direktorat Jenderal Pendidikan Tinggi (DIKTI)

Soekartawi. 2000. Pengantar Agroindustri. Jakarta (ID): Raja Grafindo Persada

Sulianta F. 2014. 101 Jurus Promosi Online Paling Top. Jakarta [ID]: Elex Media Komputindo

Sumarwan U. 2011. Perilaku, Teori dan Penerapan dalam Pemasaran. Jakarta (ID): PT Ghalia Indonesia.

[UU] Undang - Undang RI No. 20 Tahun 2008 Pasal 3 dan Pasal 6 Ayat 2-3 Tentang UMKM. [Internet]. [Diunduh tanggal 15 Januari 2019]. Jakarta (ID) Dapat diunduh di: https://www.bi.go.id/id/tentang-bi/uu-bi/Documents/ UU20Tahun2008UMKM.pdf

Wurinanda I. 2015. Efektivitas promosi produk ayam suwir "si kentung" melalui twitter [skripsi]. Bogor (ID): Institut Pertanian Bogor. 